\title{
Examining Counsellor Expertise: Evidence from the Sri Lankan Microfinance Sector
}

http://doi.org/10.21272/bel.4(1).57-67.2020

Ruwan Abeysekera, ORCID: https://orcid.org/0000-0002-2858-6483

$\mathrm{PhD}$, Senior Lecturer, Department of Finance, Faculty of Commerce and Management Studies, University of Kelaniya, Kelaniya, Sri Lanka

\begin{abstract}
Posited in the context of the exacerbating conditions of the economic crisis, the shortage of financial resources in the small and medium-sized enterprise market, and the low standard of living of the population in a number of countries, microfinancing is one of the effective tools to stimulate entrepreneurship. Microfinancing is the issuance of small loans and other services, such as business development services (BDS), which also comprise components of financial literacy, business registration, market linkages, thereby serving as a reliable mechanism to support low-income individuals to start and grow their businesses and to alleviate poverty in the country. Microfinance Institutions (MFIs) use innovative techniques, such as group lending and gradually increasing loan sizes in order to provide these services. The systematic analysis of the existing scientific literature on microfinance revealed the lack of comprehensive research on the significance of counsellor expertise in the provision of BDS. Thus, the objectives of the present study were to understand the meaning of counsellor expertise, to see how counsellor expertise could help owner-managers in different areas of their businesses, and to examine how the organizational factors affect the expertise of the counsellors. A case study method was used to carry out the study. Accordingly, six MFIs were selected as cases, and a microfinance manager, a counsellor, and three owner-managers/clients from each MFI were interviewed to collect the data. The findings show that the counsellor expertise is twofold: business knowledge and experiential knowledge. It was evidenced that, while the business knowledge of counsellors helps owner-managers in record keeping, business plan preparation, and financial literacy, the experiential knowledge helps owner-managers in networking, business linkages, and different industries. The findings also reveal that the type of MFI, the type of linkage, and counsellor selection method influence the expertise of the counsellors. Therein, the findings are useful both to the practice and the knowledge domains in microfinance setting.
\end{abstract}

Keywords: counselling, expertise, microfinance, business knowledge, experiential knowledge, business development services.

\section{JEL Classification: M14.}

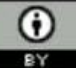

This work is licensed under a Creative Commons Attribution 4.0 International License

Cite as: Abeysekera, R. (2020). Examining Counsellor Expertise: Evidence from the Sri Lankan Microfinance Sector. Business Ethics and Leadership, 4(1), 57-67. http://doi.org/10.21272/bel.4(1).57-67.2020.

(C) The Author, 2020. This article is published with open access at Sumy State University.

\section{Introduction}

Microfinance is the provision of small loans and other services such as business development services to lowincome people to start and grow their businesses. Poverty alleviation is one of the main themes of microfinance as it is believed that there are 20.8 billion people living in the world whose daily income is less than $2 \$ s$. (Kumari et al., 2019; Khavul, 2010; World Bank, 2014; Easterly, 2006: 165). MFIs use innovative techniques such as group lending, gradually increasing loan sizes and pre-loan savings with little or low collateral to cater to low-income people that cannot be provided by the traditional baking system (CGAP, 2011; Khavul, 2010; ADB, 1997).

Sri Lanka has a well-established microfinance sector, the roots of which can be traced back to the 1900s. There are more than 10,000 MFI branches in Sri Lanka representing government, cooperative, bank and non-bank MFIs. (GTZProMis, 2010; Tilakaratne et al., 2005). The government of Sri Lanka is very keen to develop the microfinance sector due to its significance to the economy in terms of poverty alleviation, small business and livelihood development (GTZProMis, 2010; Tilakaratne et al., 2005, NEDA, 2013).

Existing studies show that MFIs need not only small loans (i.e. microcredit) but also BDS to develop businesses (Peera and Wijekoon, 2019; Fisher and Sriram, 2002; Sievers and Vandenberg, 2007). BDS include services 
such as business registration, financial literacy, market linkages, technical access, and information access that is given by the counsellors to owner managers to start new businesses and grow businesses (Sievers and Vandenberg, 2007). BDS help microenterprises to improve their productivity, competitiveness and market access and thereby increasing their sales and profits (Sievers and Vandenberg, 2007). MFIs provide BDS through counselling and training (Abeysekera, 2016). This study focuses only on counselling and in particular expertise of counsellors of MFIs. The counsellors of MFIs provide one to one and group counselling for ownermanagers free of charge. Counselling is provided to owner-managers at different locations such as MFI branch office, community centres, owner manager's business premise, his home and even on the road (Abeysekera, 2016). The counsellors must be experts in the business discipline in order to impart knowledge and skills to owner-managers. Thus, they need to have qualification and experience in businesses to provide counselling. The studies on small business (Schayek and Dvir, 2009; Chrisman and McMullan, 2004; Rice, 2002; ADEMCOL, 2001; Chrisman, 1989) reveal that counsellor expertise in terms of qualifications and experience is very important in a successful counselling intervention. However, studies show that there is no consensus on the meaning of expertise. Hence, there are many definitions given by scholars for expertise. For example, some scholars say expertise consists of intrinsic characteristics such as special knowledge or capabilities and others say it includes explicit and tacit knowledge. Additionally, studies relating to counselling in microfinance have not clearly defined the counsellor expertise and also have not found out how expertise help ownermanagers in their businesses. Further, these studies have not shown how organisational factors such as MFI type affect the expertise of counsellors. Moreover, despite the existence of studies on business counselling in the small business sector, there are hardly any studies on counselling in microfinance setting. Thus, the present study was carried out to fill these gaps by answering the following three questions: How is the expertise of the counsellors defined?; how can counsellors help owner-managers through their expertise?; and how do organisational factors affect expertise? Therein, the remainder of the article is organized as follows. The first section discusses the literature on microfinance and counselling. The research methodology is explained in the second section. And the third section presents the findings. Finally, the conclusions, discussion and implications of the study are given. In this paper client and owner-manager is used interchangeably. Client means the client of an MFI and who is an existing or potential owner-manager of a micro-enterprise. Owner manager is the owner of the microenterprise who manages it.

\section{Literature Review}

This section presents an overview of existing literature and studies conducted on counselling and the ways in which the expertise of counsellors as well as the organisational factors of MFI that could affect counselling.

\subsection{Counselling}

The counsellors of MFIs provide BDS through counselling. With regard to counselling, counsellors give advice to embryonic, aspiring and established businesses to confront problems and exploit opportunities (Abeysekera et al., 2015; Johnson, 1991). Through this process, clients develop their capabilities to assess situations, to evaluate the merits and demerits of alternatives and make informed decisions. Counsellors need to have the expertise to assist the clients so that clients achieve their personal, entrepreneurial and business objectives (Canadian APEC, IBIZ, 2015; Johnson, 1991). Studies show that counselling has helped small business firms gain better business knowledge, grow and survive, businesses and to improve sales and profits of business ventures (Cumming and Fischer, 2012; Klinger and Schündeln, 2011; Schayek and Dvir, 2009; Rice, 2002; Chrisman and McMullan, 2000).

\section{Types of counselling}

There are three types of counselling techniques available for a counsellor: Developmental counselling; Rational direction; and Crisis intervention (Boyd, 1993).

1. Developmental counselling: This is the long-time counselling given by counsellors to owner-managers. In this approach, the counsellor could help the owner-manager develop from a business idea to the marketing of the product.

2. Rational redirection: Sometimes counsellors have to mention the owner-managers that their ideas are irrational.

3. Crisis intervention: In this approach, counsellors help owner-managers when they are in trouble.

\section{The problems addressed by counselling}

Counsellors can help owner-managers to address strategic, administrative and operational problems that they face (Christman, 1989). Further, studies show that owner-managers benefited more if they obtained 
counselling at the early stage of the business so that they could face challenges successfully in the start-up, survival and performance stages of their businesses. Owner managers need assistance through counselling in market development, accessing capital and financial management, production, human resource management, and administrative processes such as accounting and risk management (Rice, 2002).

\section{Counselling in the microfinance setting}

There is a dearth of studies on counselling in microfinance setting. Counsellors of MFIs provide counselling on financial literacy, filling in loan applications, creating market linkages, input supplies, training programmes etc. (Abeysekera et al., 2015; Henry, 2006; ADEMCOL, 2001). Counsellors do not charge for counselling and they provide services at locations convenient to the clients, such as their business premises, community centres in the village, nearby MFI branch office. In addition, counsellors provide one to one and group counselling (Henry, 2006).

\subsection{Expertise and Counsellor Expertise}

As per existing literature, there is no consensus on the meaning of expertise (Huber, 1999). From the perspective of psychology, a person's expertise consists of intrinsic characteristics such as special knowledge or capabilities. From the sociological point of view, expertise is dependent on specific qualifications and status that are independent of individual differences. Further, the criterion to define expertise denotes that if a large group of people recognizes a person as an expert then he is an expert (Agnew et al., 1997; Sié and Yakhlef, 2009). Moreover, expertise involves two kinds of knowledge: explicit knowledge of a domain and tacit knowledge of a field. Further, expert knowledge could be divided into three parts: formal knowledge, practical knowledge, and self-regulative knowledge (Tynjälä,1999). Formal knowledge is the explicit and factual knowledge gained through education. Practical knowledge is the procedural knowledge which is also known as "knowing how". Formal knowledge is universal and explicit, whereas practical knowledge is personal and tacit. Self-regulative skills are reflective skills used by the person to evaluate and monitor own actions (Mugai et al., 2019; Tynjälä, 1999; Sie and Yakhlef, 2009).

Studies on small businesses show that counsellor expertise is of paramount importance in an effective counselling intervention. It is assumed that counsellor's expertise should be better than the client's expertise (Schayek and Dvir, 2009; Chrisman and McMullan, 2004; Rice, 2002; ADEMCOL, 2001; Chrisman, 1989). The literature on small businesses points out that counsellors need to have better educational qualifications, training and experience in order to provide counselling to needy clients (De Wildt, 2004). Rice (2002) conducted a study on business incubators and found out that the qualifications and experience of incubator managers enhanced the co-production in business assistance. Further, the studies on small businesses (Chrisman, 1989; Chrisman and McMullan, 2004; Gill, 2007) investigated how the outside assistance (i.e. counselling) improved the abilities of small business owners.

However, the reviewed literature has not defined the counsellor expertise holistically. The literature on microfinance has also not properly defined counsellor expertise, nor does it discuss how it helps clients (i.e. owner-managers) in different areas of businesses. Moreover, the present literature has failed to delineate the link between organisation factors and counsellor expertise in detail. Thus, the present study was carried out to fill the gaps outlined therein.

\subsection{Organisational factors that may affect the expertise of the counsellors}

Organisational factors such as type of MFI and types of linkage could influence the expertise of the counsellors.

\section{Types of MFIs}

There are four MFI types as given below (Jansson et al., 2004):

$>$ Non-profit MFIs (e.g. NGOs);

Bank MFIs;

Non-bank MFIs;

Cooperative/credit union MFIs.

These MFIs are different from each other in terms of objectives, management, investors, market segments etc. For example, cooperative/NGO MFIs may have to achieve more social objectives compared to a bank MFIs that wants to achieve more profit based objectives. Moreover, bank MFIs might consider better educational qualifications than cooperative MFIs when recruiting counsellors. Thus, the type of MFI could influence the expertise of the counsellors. 


\section{Types of Linkages}

Types of linkages between the provision of credit and BDS is another organisational factor that may influence counsellor expertise. In this respect, Dunford (2001) has identified three linkages that MFIs can use to link the provision of microcredit and BDS.

Three linkages are:

1. Unified: credit and BDS are provided by the same people.

2. Parallel: credit and BDS are provided by different people and they work in two different departments in an organization.

3. Linked (partner): credit and BDS are provided by two different organisations and in general, these organisations collaborate with each other by introducing clients.

The advantage of having unified linkages over the parallel linkages is the cost advantage given that the same people are involved in delivering both credit and marketing. However, when it comes to expertise, people (e.g. counsellors) working in parallel linkages are in a more advantageous position compared to that of unified, as they do not have to attend to two tasks and thus have enough time to specialise in one area (Sievers and Vandenberg, 2007). Thus, the type of linkage between the provision of credit and BDS could possibly influence the counsellor expertise.

\section{Methodology}

Exploring the expertise of counsellors in microfinance settings is a contemporary phenomenon which has not been examined in depth by researchers. Thus, the case study method is a suitable approach allowing for the exploration of the phenomenon in depth (Yin, 2009).Further, this study uses the multiple case study method instead of the single case study, thereby enhancing the theoretical generalisation which is an objective of conducting a qualitative study.

The unit of analysis for this study was individuals working for MFIs and owner-managers of micro-enterprises. Six cases (i.e. MFIs) were selected for this study which were in line with 4-6 cases proposed by Eisenhard (1989) for a multiple case study.

Six cases (i.e. MFIs) and respondents were selected using the purposive sampling technique. Six cases were selected based on the MFI type (i.e. Government, bank, NGO, cooperative) and type of linkages (i.e. Unified, parallel). Two officers (counsellor and manager) from MFI and three owner-managers who obtained services from MFIs were chosen for the study.

The details of the MFIs chosen for the study are given below in Table 1.

Table 1. Types of MFIs chosen for the study

\begin{tabular}{|l|l|l|}
\hline \multicolumn{1}{|c|}{ MFIs } & \multicolumn{1}{c|}{ Type of MFI } & \multicolumn{1}{c|}{ Type of Linkage } \\
\hline MFI-1 & Private Non-bank & Parallel \\
\hline MFI-2 & Cooperative /credit union & Parallel \\
\hline MFI-3 & Private Bank & Unified \\
\hline MFI-4 & Government, Non-Bank & Unified \\
\hline MFI-5 & NGO & Unified \\
\hline MFI6 & Government & Unified \\
\hline
\end{tabular}

Source: Compiled by the author

Before the data collection commenced, a pilot study was carried out to refine the semi-structured questionnaires. 24 in-depth interviews (i.e. four interviews from each case) were conducted and each interview took about 45-60 minutes. All the interviews were tape-recorded and then transcribed. Informed consent was taken from each respondent before the interviews were conducted for ethical reasons.

Thematic analysis was used to analyse the data. When analysing data, techniques and strategies such as pattern matching and cross-case synthesis were used. When carrying out the study, validity and reliability were addressed. Construct validity was achieved by using multiple data sources such as interview data, observations and company records. Internal validity, which looks for causal relationships was met by using the pattern matching technique in the data analysis. External validity was achieved by focusing the study on multiple cases that help generalise the findings. Through the multiple case study approach, the findings could be generalised to a certain extent, though the main objective of a qualitative study is a theoretical generalisation as opposed to statistical generalisation (Yin, 2009). Reliability points to whether the operations of the study such as data collection could be repeated with the same results. In this study, a case study protocol was used so that the same results could be obtained by repeating the study again (Yin, 2009). 


\section{Findings}

The findings show that counsellors (field officers) of MFIs use regular group/society meetings to provide counselling. Besides, counsellors visit clients at their home/operating bases to do this. Group/society meetings of clients are held in temples, schools and community centres close to clients' operating bases and homes. Counsellors provide both group and one-to-one counselling and play a vital role in providing BDS to clients. They provide developmental, rational redirection and crisis intervention counselling. They have the skills and the competencies to organise training and trade fairs for clients in addition to their main counselling roles. Counselling is not compulsory for clients to obtain other services and it is provided free of charge.

The thematic analysis was based on the main research questions: how is counsellor expertise defined?; how can counsellors help managers through their expertise; and how do organisational factors affect counsellor expertise? The key findings of the study are given below in Table 2.

Table 2. The key findings of the Case Studies

\begin{tabular}{|l|l|}
\hline \multicolumn{1}{|c|}{ Research Question } & \multicolumn{1}{c|}{ Key findings } \\
\hline How is counsellor expertise defined? & $\begin{array}{l}\text { Counsellor expertise can be defined in terms of business knowledge and experiential } \\
\text { knowledge. }\end{array}$ \\
\hline $\begin{array}{l}\text { How can counsellors help owner- } \\
\text { managers through their expertise? }\end{array}$ & $\begin{array}{l}\text { Counsellors can help owner-managers in the areas of financial literacy, record keeping and } \\
\text { business plan preparation using their business knowledge. They use their experiential } \\
\text { knowledge to help owner-managers in different industries, networking and different } \\
\text { subjects such as business registration, business plan preparation. }\end{array}$ \\
\hline $\begin{array}{l}\text { How do organisational factors affect } \\
\text { counsellor expertise? }\end{array}$ & $\begin{array}{l}\text { Type of MFI, Type of linkage and counsellor selection method affect the counsellor } \\
\text { expertise }\end{array}$ \\
\hline
\end{tabular}

Source: Compiled by the author

The following section describes each of the key findings under each research question.

\section{Research Question 01. How is counsellor expertise defined?}

The findings reveal that counsellors' expertise consists of business knowledge and experiential knowledge. Business knowledge refers to the knowledge acquired by the counsellors through qualifications such as degrees, diplomas related to business and by following training programmes. In contrast, experiential knowledge refers to the knowledge acquired through working with MFIs, owner-managers and by engaging in own businesses.

\section{Business knowledge}

All the respondents of MFIs were of the view that they considered the qualifications of the counsellors when recruiting them and later they were given the training to upgrade their knowledge. Given below is an excerpt to support the importance of business knowledge gained through qualifications.

The Enterprise Promotional Manager of MFI-2 expressed that:

"We recruit counsellors with diplomas and degrees in business and later we provide them training related to the business disciplines. We believe that the business knowledge of counsellors gained through qualifications helps them in performing their job".

\section{Experiential knowledge}

The findings across all the cases show that experiential knowledge gained through working with ownermanagers, MFIs and working in own businesses are vital to become a good counsellor. When recruiting, MFIs look at the experiential knowledge of the counsellors. MFI-5 and MFI-6 gave more prominence to experiential knowledge when recruiting the counsellors.

The general manager of MFI-5 highlighted the importance of experiential knowledge.

"We always value experience when recruiting our counsellors. We believe that hands-on experience is more vital than qualifications. Our counsellors must be familiar with our lending and BDS having worked for us before being appointed as counsellors".

The following quotation shows that experiential knowledge can be gained through working with MFIs and other organisations.

The counsellor from MFI-2 stated:

"Everybody cannot become a good counsellor. I have got 20 years' experience as a counsellor. I started my counselling profession with an American Project in Mahaweli, where I had to give advice to farmers and to develop them. I had worked for 6 years there before I joined Mackwoods Agro Chemicals to counsel 
some farmers in Nuwaraeliya. Then I joined MFI-2 and worked there for 6 years before I joined MFI-1, my current workplace. I learnt enterprise development services from MFI-2, as earlier I was only exposed to agriculture".

The findings from MFI-5 and MFI-6 show that the counsellors gained experiential knowledge by working in their own businesses. MFI-5 and MFI-6 used its clients as counsellors. This is substantiated by the following example.

The counsellor from MFI-6 said that:

"I sew garments and sell at home. So I have experience in the business. This helps me in counselling".

\section{Question 2: How do counsellors help owner-managers through expertise?}

The findings show that counsellors use business knowledge to help owner-managers in areas such as financial literacy, record keeping and business plan preparation. The following examples show how counsellors help owner-managers through their business knowledge.

The counsellor of MFI-3 stated that he could help owner-managers with financial literacy, record keeping and business plan preparation.

"I have passed the Advanced Level in the Commerce subject stream. Right now I am following banking exams. Our bank also gives us training in financial literacy, record keeping and business plan preparation. I always use this knowledge gained through qualifications when I provide counselling to clients".

The counsellor from MFI-3 stated below how he used business knowledge to help owner-managers with financial literacy.

"Many microfinance clients do not know how to manage their cash flows and pay off loans. For example, sometimes the clients get payment for sales after two months (credit sales), but still, they have to pay the loan. Further, when they get the money (excess cash) they do not know what to do. When it comes to the funding they sometimes go to informal money lenders and pay very high-interest rates. Hence we have to counsel them on how to manage cash flows, save, invest, manage loans etc.".

The counsellor from MFI-5 stressed the importance of business knowledge in helping the owner-managers with record keeping and financial literacy.

"Most of the microfinance clients do not know how to keep records and often they utilise most of their profit for personal transactions. So when we provide counselling we always educate them on how to keep records separately for business and personal transactions and to calculate profits. We also educate them on how to save money because, without the saving habit, one cannot do business. All this knowledge I learnt through the training given by MFI-5 to us".

The owner-managers who were interviewed also agreed that the counsellors help them with their business knowledge.

The owner-manager -1 from MFI-1 stated that:

"Our counsellors are knowledgeable. Counsellors taught me how to prepare a business plan. This is very important, not only to obtain credit from financial institutions but also to manage my business".

The findings also reveal that experiential knowledge falls into three categories: subject-specific, networking specific, and location/industry-specific.

The following quotations show how subject-specific experiential knowledge is used by counsellors to handle problems in business registration and packaging.

The counsellor from MFI-1 stated that:

"Some clients do not know where to register their business. Some with a business already started a few years back do not have a business registration. So, we advise them to register the business at the provincial council saying that they are going to start the business with the help of the MFI. Otherwise, the provincial council will fine them for delaying the registration".

The counsellor added that:

"If the client does not know how to package, I ask him to go to the supermarket and buy a packet of a gram and observe the packaging. I tell him that customers first get attracted to the packaging and then 
they buy. If the quality is good, then they buy the product again. I ask the client to design a better packaging for his product after seeing the packaging at the supermarket".

The findings reveal that the counsellors possess networking specific experiential knowledge that they use to create a market, loan and training linkages. The following quotations supported this.

The counsellor of MFI-3 stated that he created market linkages.

"I have been in this area (Kiridwela; an area famous for pineapple cultivation) for five years. Here you find most clients with pineapple cultivation. I know pineapple exporters since I am familiar with the sector. I introduce my pineapple grower clients to these exporters. So my clients do not have to worry about the market".

The counsellor from MFI-3 explained how he created loan linkages for his clients.

"When the client has used up the maximum loans that we provide, then we encourage the client to obtain loans from other financial institutions and we introduce such institutions (e.g. Banks). Moreover, we advise clients to open an account with the bank and maintain the account for three months so that he can request a loan. Moreover, we ask the client to meet the manager of the bank and show the products he produces (e.g. A packet of a gram) so that the client can develop a relationship with the manager. This is also counselling, as the client does not know these things".

The counsellor from MFI-1 described how he linked the clients to training programmes (training linkages).

"For example, a client who manufactures murukku (a spicy snack) may not earn a good profit due to his lack of knowledge in business. So I introduced him to business training programmes such as record keeping and marketing, which helped him organise his business better and make more profit".

The findings reveal that the counsellors demonstrate industry/location-specific experiential knowledge. This was evidenced by the following statement.

The counsellor from MFI-3 declared:

"Here in this area (Kiridiwela), we find many clients engaging in pineapple cultivation. So I need to be an expert on that. I know clients need Rs.130,000 to grow an acre of pineapples. I know what the profit margin is for one acre of pineapple cultivation. Similarly, a counsellor working in Maharagama should be an expert in garments, as most of the clients are involved in the ready-made garment industry there. Likewise, counsellors in different geographical areas are specialised in different industries. This industry/location-specific knowledge helps us, counsel clients, better".

The owner-managers of all the cases agreed that they benefited from the counsellor's experiential knowledge. Given below is an example to support this.

Owner Manager-2 from MFI-2 expressed:

"When I wanted Rs. 300,000 for my coir business, our counsellor arranged this loan amount from a bank as MFI-2 could not provide that amount".

The findings also suggest that counsellors need both business and experiential knowledge to provide counselling in certain instances. The following example illustrates this point.

The counsellor from MFI-3 stated that:

"Today a microfinance client came and requested Rs.500, 000 for pineapple cultivation. However, I know that such an amount is not needed at the outset, and initially, you need about Rs. 75,000 to plant and after 7-8 months you need Rs. 125,000 for fertilizer. I told her if she wanted Rs.500,000 she would have to pay interest and she needed to borrow the money in stages. You see, this type of counselling is very important".

The example above shows that counsellor needed both business knowledge (i.e. Interest rates) and experiential knowledge (i.e. industry knowledge on pineapple).

\section{Research question 03. How do organisational factors affect expertise of counsellors?}

The difference in the expertise of counsellors could be due to the organisational factors such as the type of MFIs, the type of linkage used and the counsellor selection method. Table 3 compares the organisational factors of counsellors and expertise. 
Table 3. Organisational factors and counsellors expertise

\begin{tabular}{|c|c|c|}
\hline & $\begin{array}{l}\text { Organisational factors (a } \\
\text { type of MFIs, type of } \\
\text { linkage, method of selection) }\end{array}$ & Counsellor expertise and BDS delivered \\
\hline$\frac{7}{i}$ & $\begin{array}{l}\text { 1) Non-Bank } \\
\text { 2) Parallel linkage } \\
\text { 3) Through advertisements } \\
\text { Professionals are selected as } \\
\text { counsellors }\end{array}$ & $\begin{array}{l}\text { 1) Degree/Diploma in Business Management. } \\
\text { 2) Received training from MFI in financial literacy, business plan preparation and basic } \\
\text { business management. } \\
\text { 3) } 20 \text { years' experience in business counselling. } \\
\text { BDS provided } \\
\text { 1) Business idea generation and business plan preparation. } \\
\text { 2) Administrative processes e.g.Record keeping. } \\
\text { 3) Human resource management, e.g.Employee provident funds. } \\
\text { 4) Market development, sales and distribution, } \\
\text { e.g.Market linkages, producer groups. } \\
\text { 5) Accessing capital and financial management, } \\
\text { e.g.Financial literacy, loan linkages, loan management. } \\
\text { 6) Development and production of the firm's products or services. }\end{array}$ \\
\hline$\frac{N}{i}$ & $\begin{array}{l}\text { 1) Credit union } \\
\text { 2) Parallel linkage } \\
\text { 3) Through advertisements } \\
\text { Professionals are selected }\end{array}$ & $\begin{array}{l}\text { 1) Degree /Diploma in Business Management. } \\
\text { 2) Received training from MFI in financial literacy, business plan preparation and basic } \\
\text { business management. } \\
\text { 3) } 10 \text { years' experience in business counselling } \\
\text { BDS provided } \\
\text { 1) Business idea generation and business plan preparation. } \\
\text { 2) Administrative processes, } \\
\text { e.g. Recordkeeping. } \\
\text { 3) Human resource management. } \\
\text { 4) Market development, sales, and distribution. } \\
\text { 5) Accessing capital and financial management, } \\
\text { e.g.Financial literacy. } \\
\text { 6) Development and production of the firm's products or services. }\end{array}$ \\
\hline$\frac{\substack{1 \\
\Sigma}}{\sum}$ & $\begin{array}{l}\text { 1) Private Banks } \\
\text { 2) Unified linkage } \\
\text { 3) Through advertisements } \\
\text { Professionals are selected. }\end{array}$ & $\begin{array}{l}\text { 1) Advanced Level examination and banking examinations. } \\
\text { 2) Received training from MFI in financial literacy, business plan preparation. } \\
\text { 3) } 6 \text { years' experience in business counselling. } \\
\text { BDS provided } \\
\text { 1) Business idea generation and business plan preparation. } \\
\text { 2) Administrative processes, } \\
\text { e.g. Recordkeeping. } \\
\text { 3) Market development, sales and distribution. } \\
\text { 4) Accessing capital and financial management, } \\
\text { e.g.Financial literacy. }\end{array}$ \\
\hline$\stackrel{+}{i}$ & $\begin{array}{l}\text { 1) Government non-bank } \\
\text { 2) Unified linkage } \\
\text { 3) Through advertisements } \\
\text { Professionals are selected. }\end{array}$ & $\begin{array}{l}\text { 1) Advanced Level examination. } \\
\text { 2) Received training from MFI on financial literacy. } \\
\text { 3) } 3 \text { years' experience in business counselling. } \\
\text { BDS provided } \\
\text { 1) Business idea generation and business plan preparation. } \\
\text { 2) Administrative processes, } \\
\text { e.g. Recordkeeping. } \\
\text { 3) Accessing capital and financial management, } \\
\text { e.g. Financial literacy. } \\
\text { 4) Market development, sales and distribution, } \\
\text { e.g. Market linkages, producer groups. }\end{array}$ \\
\hline$\frac{n}{1}$ & $\begin{array}{l}\text { 1) NGO } \\
\text { 2) Unified linkage } \\
\text { 3) Selected from clients. }\end{array}$ & $\begin{array}{l}\text { 1) No proper formal education and 2) training received on financial literacy or business plan } \\
\text { preparation. } \\
\text { 3) } 3 \text { years' experience in business counselling. } \\
\text { BDS provided } \\
\text { 1) Business idea generation and business plan preparation. } \\
\text { 2) Administrative processes, } \\
\text { e.g. Recordkeeping. } \\
\text { 3) Accessing capital and financial management, } \\
\text { e.g.Financial literacy. }\end{array}$ \\
\hline $\begin{array}{l}0 \\
\stackrel{1}{1} \\
\sum_{i}\end{array}$ & $\begin{array}{l}\text { 1) Government } \\
\text { 2) Unified linkage } \\
\text { 3) Selected from clients. }\end{array}$ & $\begin{array}{l}\text { 1) No proper formal education and training received on financial literacy or business plan } \\
\text { preparation. } \\
\text { 2) } 1 \text { year of experience in business counselling. } \\
\text { BDS provided } \\
\text { 1) Business idea generation and business plan preparation. } \\
\text { 2) Administrative processes, } \\
\text { e.g. Recordkeeping. } \\
\text { 3) Accessing capital and financial management, } \\
\text { e.g.Financial literacy. }\end{array}$ \\
\hline
\end{tabular}

Source: Compiled by the author 
According to Table 3, counsellor expertise varies due to the type of MFI, the type of linkage and counsellor selection method. The counsellors attached to MFI-1 and MFI-2 show more expertise than counsellors of other MFIs. As can be seen in the table, they provide more BDS compared to other counsellors. This could be due to their superior business and experiential knowledge. Their expertise is influenced by the type of selection method that seeks better educational qualification and parallel linkage that allows them to improve their expertise.

The counsellors from MFI-5 and MFI-6 were good at experiential knowledge compared to other counsellors. This could possibly due to the counsellor selection method adopted by these MFIs. These MFIs selected counsellors from the clients who had experience in MFI's products as they had been in the client groups formed by MFIs. Further, these clients were often self-employed. However, these counsellors worked for the MFIs on a part-time basis as they were self-employed. Working part-time could affect the expertise negatively as they do not have much time to improve by engaging in learning activities.

The expertise of counsellors could be affected by the type of MFI also. The counsellors of government MFIs (e.g. MFI-6) showed less expertise, especially in terms of business knowledge. This was possibly due to their selection method and poor Human Resource Development strategies in terms of providing training to the counsellors.

\section{Discussion, conclusions and implications}

The findings show that counsellor expertise can be defined in terms of business knowledge and experiential knowledge. Further, the counsellors could help owner-managers in financial literacy, record keeping, and business plan preparation by using their business knowledge whereas they could help owner-managers in areas such as business registration (subject-specific), market linkages (networking specific), and specific industries (location/industry-specific) through their experiential knowledge. Moreover, the findings reveal that counsellor expertise could be influenced by organisational factors such as type of MFI, the type of linkage, and the counsellor selection method.

The existing literature does not define the expertise precisely in terms of business, and therefore, does not support the finding of this study. The previous studies (Rice, 2002; Chrisman, 2004) discuss only the importance of qualifications and experience of counsellor expertise in counselling and have failed to define expertise. Hence, defining the expertise of counsellors is a new finding. Further, the existing literature is silent on how the expertise of the counsellors could be used to help owner-managers in different areas and how the organisational factors influence the expertise of the counsellors. Thus, this study fills these gaps as well.

Given that counsellor, expertise is very important to improve the performance of owner-managers. MFIs must take actions to improve expertise. MFIs could consider the educational qualifications and experience when recruiting counsellors. Further, MFIs could give on the job training to the newly recruited counsellors under the senior counsellors and provide continuous training. Giving training could be costly at times, thus MFIs must think about training junior counsellors through mentoring given by the senior counsellors. Moreover, MFIs having unified linkages should think about the workload of the counsellors that affect their expertise. MFIs have to give serious thought to part-time counsellor though they possess better experiential knowledge being engaged in businesses as they do not have time to improve their business knowledge nor impart the expertise. Future researchers can conduct similar research in different geographical regions with different organisational factors on counsellor expertise.

\section{References}

1. Abeysekera, R. (2016). Enhancing entrepreneurship in Sri Lanka: the provision of business development services (BDS) by microfinance institutions to support the self-sufficiency of microenterprises (Doctoral dissertation, Bournemouth University). Available from: http://eprints.bournemouth.ac.uk/24721/.

2. Abeysekera, R., Patton, D., \& Mullineux, A. (2015). Co-production in Business Counselling in Microfinance Setting: A conceptual approach. Journal of Enterprising Culture, 23(03), 299-319. https://doi.org/10.1142/S0218495815500107.

3. Agnew, N.M., Ford, K.M. and Hayes, J.P. (1997). Expertise in context: personally constructed, socially selected, and reality-relevant?, in Feltovich, P.J., Ford, K.M. and Hoffman, R.R. (Eds), Expertise in Context, AAAI Press, Menlo Park, CA, pp. 219-44. Available from: https://www.researchgate.net/profile/Kenneth_Ford/publication/258857150_Expertise_Socially_Situated _Personally_Constructed_and_'Reality'_Relevant/links/0c960529e3900745cb000000.pdf. 
4. ADB (1997). Microenterprise development: Not by credit alone. Manila: Asian Development Bank. Available from: https://www.findevgateway.org/library/microentreprise-development-not-credit-alone.

5. ADEMCOL (2001). Asociacio'n para el Desarrollo Microempresarial Colombiano and Women's Opportunity Fund: Bundling microfinance and business development services. A case study from ADEMCOL in Colombia, Microenterprise Best Practices. Washington, DC: United States Agency for International Development.

6. Boyd, J. A. (1993). A business advisor's guide to counselling theories. Small business forum, Spring, 4556. Available from: https://eric.ed.gov/?id=ED369008.

7. Canadian APEC, IBIZ (2015). Asia Pacific Economic Cooperation, International network of institutes of small business counsellors. Available from: http://www.xlin.com/business-counselling.html [Accessed 12 September 2019].

8. CGAP (2011). Advancing financial access to world poor [online]. Washington: Consultative group to assist the poor. Available from: http://www.cgap.org/p/site/c/about/ [Accessed 20 September 2019].

9. Chrisman, J. J. and McMullan, W. E. (2004). Outsider assistance as a knowledge resource for new venture survival. Journal of Small Business Management, 42(3), 229-244. https://doi.org/10.1111/j.1540627X.2004.00109.x.

10.Chrisman, J. J. (1989). Strategic, administrative, and operating assistance: The value of outside consulting to pre-venture entrepreneurs. Journal of business venturing, 4(6), 401-418. https://doi.org/10.1016/08839026(89)90010-4.

11.Chrisman, J. J., and McMullan, W. E. (2000). A Preliminary assessment of outsider assistance as a knowledge resource: the longer-term impact of new venture counselling. Entrepreneurship theory and practice, 24(3), 37-53. Available from:

https://journals.sagepub.com/doi/abs/10.1177/104225870002400303.

12.Cumming, D. J. and Fischer, E. (2012). Publicly funded business advisory services and entrepreneurial outcomes. Research Policy, 41(2), 467-481. https://doi.org/10.1016/j.respol.2011.09.004.

13.De Wildt, M. (2004). Linking business development services to financial services: The case of Financiera Solucio'n. Geneva: ILO. Available from: http://www.bdsknowledge.org/dyn/bds/docs/422/MdRdWPeru.pdf [Accessed 10 September 2019].

14.Dunford, C. (2001). Building better lives: Sustainable linkage of microcredit and education in health, family planning and HIV/AIDS prevention for the poorest entrepreneurs. Washington DC: Freedom from Hunger, commissioned by Microcredit Summit Campaign. Available from: https://pdfs.semanticscholar.org/cb44/d870c4f2f4f7026dd3ef7223396e2d36bff8.pdf.

15.Easterly, W. (2006). The white man's burden: Why the West's efforts to aid the rest have done so much ill and so little good. New York: Penguin Press. https://doi.org/10.1111/j.1746-1049.2008.068_2.x.

16.Eisenhardt, K. M. (1989). Building theories from case-study research. Academy of management review, 14(4), 532-550. https://doi.org/10.5465/amr.1989.4308385.

17.Fisher, T. and Sriram, M. S. (2002). Beyond micro-credit: Putting development back into micro-finance. New Delhi: Vistar Publications. https://policy-practice.oxfam.org.uk/publications/beyond-micro-creditputting-development-back-into-micro-finance-122837.

18.Gill, D. (2007). Catching up with the New Jersey SBA and small business development centres. NJBIZ (New Jersey's Business Journal), 20(34), 19.

19.GTZ ProMiS (2010). Micro Finance Industry Report. Sri Lanka: GTZ ProMiS and The Banking With the Poor Network. Available from: https://www.findevgateway.org/sites/default/files/mfg-en-papermicrofinance-industry-report-sri-lanka-2010.pdf.

20.Henry, S. (2006). Good practice in business development services: How do we enhance entrepreneurial skills in MFI clients? [Online]. Toronto: Alterna Savings. Available from: http://www.ruralfinanceandinvestment.org/node/59.

21.Huber, B. (1999). Experts in organizations: the power of expertise. Academy of business and administrative science conference. Available from: www.sba.muohio.edu/abas/1999/huberbe.pdf.

22.Jansson, T., Rosales, R. and Westley, G. (2004). Principles and Practices for Regulating and Supervising Microfinance. Washington, DC: Inter-American Development Bank. Available from: https://publications.iadb.org/en/publication/11768/principles-and-practices-regulating-and-supervisingmicrofinance.

23.Johnson, D. J. (1991). Counselling business startups and owner-managers of small firms: a psychological study, Part 1. Journal of Workplace Learning, 3(5), 10-14. https://doi.org/10.1108/EUM0000000002866.

24.Khavul, S. (2010). Microfinance: Creating Opportunities for the Poor? Academy of management perspectives, 24(3), 58-72. https://doi.org/10.5465/amp.24.3.58. 
25.Klinger, B., and Schündeln, M. (2011). Can the entrepreneurial activity be taught? Quasi-experimental evidence from Central America. World Development, 39(9), 1592-1610. https://doi.org/10.1016/j.worlddev.2011.04.021.

26.Kumari, J. P., Azam, S. F., and Khalidah, S. (2019). The Effect of Microfinance Services on Poverty Reduction: Analysis of Empirical Evidence in Sri Lankan Perspectives. European Journal of Economic and Financial Research of Enterprising Culture, 23(03), 299-319. Available from: https://www.oapub.org/soc/index.php/EJEFR/article/view/654.

27.Mugai, W. J. J., Nyaga, V. K., and Mburugu, B. M. (2019). Counsellor's Knowledge Power on Counselling Outcomes of Learners with Behavioural problems in Public Primary Schools in Embu County Kenya. Counsellor, 4(6). Available from: https://ijisrt.com/wp-content/uploads/2019/07/IJISRT19JU67.pdf.

28.NEDA (2013). Microenterprise policy paper [Online]. Sri Lanka: National Enterprise Development Authority. Available from: https://www.neda.gov.lk/web/index.php?lang=en.

29.Perera, M. A. M. I., and Wijekoon, W. M. S. M. (2019). Role of Microfinance in Empowering Poor Rural Households: A Case Study in Berendina in Sri Lanka. Sri Lanka Journal of Business Economics, 8(1). Available from: http://journals.sjp.ac.lk/index.php/sljbe/article/view/3937.

30.Rice, M. P. (2002). Co-production of business assistance in business incubators - An exploratory study. Journal of business venturing, 17(2), 163-187. https://doi.org/10.1016/S0883-9026(00)00055-0.

31.Schayek, K. and Dvir, D. (2009). Measuring the effect of public assistance programs on small businesses' performance. Journal of general management, 35(2), 3-20. https://doi.org/10.1177\%2F030630700903500202.

32.Sié, L. and Yakhlef, A. (2009). Passion and expertise knowledge transfer. Journal of Knowledge Management, 13(4), 175-186. https://doi.org/10.1108/13673270910971914.

33.Sievers, M., and Vandenberg, P. (2007). Synergies through linkages: who benefits from linking microfinance and business development services? World Development, 35(8), 1341-1358. https://doi.org/10.1016/j.worlddev.2007.04.002.

34.Tilakaratne, G., Wickramsinghe, U. and Thusitha, K. (2005). Microfinance in Sri Lanka: a household level analysis of outreach and impact on poverty. Sri Lanka: Institute of Policy Studies of Sri Lanka. Available from: http://www.pep-net.org/sites/pep-net.org/files/typo3doc/pdf/files_events/4th_colombo/Ganga.pdf.

35.Tynjälä, P. (1999). Towards expert knowledge? A comparison between a constructivist and a traditional learning environment in the university. International journal of educational research, 31(5), 357-442. https://doi.org/10.1016/S0883-0355(99)00012-9.

36.World Bank (2014). Poverty Review [Online]. Washington DC: World Bank. Available from: http://www.worldbank.org/en/topic/poverty/overview [Accessed 18 September 2019].

37.Yin, R. K. (2009). Case-study research: Design and methods 4th edition ed. London: Sage. 